\title{
Strategies of Training Intercultural Communication Competence in Basic Teaching of Business Japanese
}

\author{
Xiaofei Gao \\ Dalian Neusoft University of Information \\ Dalian, China 116023
}

\begin{abstract}
In the 21st century with increasingly frequent cultural exchange, one of the important objectives of basic teaching of business Japanese is to train students' intercultural communication competence. They will hold an open attitude toward foreign culture through learning it and comparing domestic culture and foreign one. Proper teaching methods in knowledge, skills and attitudes enable students to adapt their verbal behavior and non-verbal behavior to changing circumstances and communicate smoothly.
\end{abstract}

Keywords-intercultural communication competence; basic teaching of business Japanese; knowledge; skill; attitude

\section{INTRODUCTION}

The training of intercultural communication competence is indispensable in training application-oriented Japanese business talents. The learning of Japanese language includes vocabularies and grammars and expression skills. Meanwhile, intercultural communication competence is of vital importance in communication. Therefore, the Syllabus for Elementary Stage of Japanese Major in Universities (2001) adds "social culture" on the basis of "voice", "character and vocabulary", "grammar", "sentence pattern" and "Functional-notional approach", in order to train students' intercultural communication competence. Language knowledge and skills are foundations of verbal communication skills. [1] It stipulates in National Standard for Teaching Quality of Japanese Major in Universities (2014) that "Japanese majors should have Japanese application ability, literature appreciation ability, intercultural communication competence, critical thinking skills and innovation ability, research ability, autonomous learning ability and practical ability"; "intercultural communication competence" is listed as the third important ability of Japanese majors; the course of "intercultural communication" is deemed as core course; the training program of Japanese majors explicitly proposes "international communication activities are organized to let students feel social culture of Japan, expand their international view and improve intercultural communication competence". [2] Business Japanese teaching trains three skills including business skills, verbal communication skills and intercultural communication skills [3]. How to train students' intercultural communication competence is one of the important research topics in business Japanese education.

\section{DEFINITION AND CONNOTATION OF INTERCULTURAL COMMUNICATION COMPETENCE}

Scholars with Hammer (1989), Byram (1997), Bennett \& Allen (1999) as representatives give different definitions on "intercultural communication competence". Because they hold different opinions on connotation of intercultural communication competence, the definition of "intercultural communication competence" hasn't been unified. Nevertheless, the most popular definition among intercultural scholars is "the ability based on personal intercultural knowledge, skills and attitudes and showed in intercultural communication in order to effectively and properly communication" [4].

National Standard for Teaching Quality of Japanese Major in Universities (2014) defines "intercultural communication competence" as: students understand the diversification of world through language study, hold an open attitude towards multicultural phenomenon; keenly observe and reasonably explain cultural difference; flexibly use strategies to fulfill tasks of intercultural communication; help Chinese and Japanese to realize effective intercultural communication. [2]

To sum up, although expressions of intercultural communication competence are different, most scholars have reached a consensus that knowledge, skills and attitudes are major elements of intercultural communication competence. [5]

In knowledge training, the following aspects are distinctly important:

First, continuously accumulate knowledge about domestic and foreign culture and analyze to understand their differences. Communication and culture are indispensable. Communication approach is acquired from cultural knowledge. Differences of values, habits and behavioral patterns can be understood through learning cultural knowledge.

Second, keep the influence of context on communication in mind. Context was first proposed by British anthropologist Malinowski in 1923. He finds only knowing the meanings of words is far from enough to know what others want to express. Language and environment are closely linked. American anthropologist Edward Hall proposes "high-context culture" and "low-context culture" from the perspective of intercultural communication. Japanese people highly depend on context in communication, namely Japan has high-context culture. In high-context cultural communication, few part of information directly appears in the language of addressors and listeners. 
Most information is contained in context of addressors or people's heart. Therefore, when communicating with Japanese, we need to grasp the real intention of addressors according to context, tone, expression and environment and understand their implication.

Third, improve Japanese verbal and non-verbal skills. Verbal skill means using Japanese according to pronunciation and grammar, communicating through proper language according to different scenes, objects or situations. However, in reality, more than 65 to 70 percent of information is conveyed through non-verbal communication. Non-verbal communication approaches differ in different cultures. Cultural shock will be caused if we lack knowledge in it.

In skills training, the following aspects are important:

First, train ability to build good relationship with people. Build good relationship with people with foreign culture and keep sustainable development.

Second, train ability of equal communication. When holding different opinions from others, clearly express our opinions but respect others and support them to voice their opinions.

Third, compare and observe similarities and differences of domestic and foreign cultures. Review domestic culture and communication after comparison and observation.

In attitude training, the following aspects are important:

First, burst with curiosity about foreign culture and treat it with open attitude, so that we are more interested and willing to understand actively. We should hold open attitudes toward cultural difference.

Second, have cultural relativism and foreign culture consciousness. The training of foreign culture consciousness based on cultural relativism is distinctly important to carry out smooth intercultural communication. The core of cultural relativism is "admit and respect different cultures and communication equally". Therefore, we should hold objective and equal attitudes and respect differences in behaviors caused by different cultures and modestly learn merits of other cultures. Meanwhile, respect values of domestic and foreign cultures and realize equal communication and mutual learning.

In business Japanese teaching, it is ideal to train students through integration of knowledge, skills and attitudes. However, at present, attentions are paid to teaching knowledge about business Japanese and business etiquette. The training of intercultural communication competence is backward. Teaching methods to more effectively train students' intercultural communication competence are discussed as follows.

\section{TRAINING OF INTERCULTURAL COMMUNICATION COMPETENCE}

\section{A. Make the Best of Movie and Video Materials}

Movie and video materials reflect real life of people who communicate through first language. With interestingness, real language and scenes and diversified contents and forms, it can be used as teaching material to train students' intercultural communication competence. Because it has pictures and texts, integrates viewing, listening and speaking and contains emotions and thoughts, compared with textbooks or audio data, it is more outstanding in stimulating students' interests. At the meantime, students can feel the realest language atmosphere and experience authentic language expression and grasp sentence patterns and improve language competence and accuracy degree of Japanese. Non-verbal behaviors appearing in movies and videos contain Japanese culture, customs and behavioral habits. Instead of letting students see casually, teachers properly guide students before appreciating and analyzing movies and videos and design problems for students and then evaluate reasonably, such as let students play roles and write the favorite classic lines.

\section{B. Use Case Analysis Method}

Cases around us and of foreign cultural shock happened in reality published in newspapers and magazines are collected and introduced. Students are asked to discuss and analyze characteristics of characters' cultural background and reasons for misunderstanding or cultural friction in cases.

For example, a case once happened on Japanese business occasion:

A Chinese journalist interviews in a Japanese company. The receptionist says with a smiling face,

$$
\text { 日本の招待側「すぐにお返事にしかねますので...」 }
$$

(I cannot answer you immediately...)

中国の記者「要するに、ダメということですか」(Do you refuse to be interviewed in any way?)

As a result, the two sides part on bad terms. As for this case students can discuss the reasons. How Chinese journalist should respond to be more appropriate. Students draw the following conclusions through discussion and analysis. (1) The answer of Japanese receptionist implies "refuse the interview". (2) But the female Chinese journalist fails to accurately understand the "implication" and gives inappropriate answer, so they part on bad terms. (3) Japanese think "harmony" is precious. In order to avoid letting others feel embarrassed, they will not directly say “いいえ” to refuse others but let others understand their feelings politely. (4) Japanese is "ambiguous language". (5) The real intentions of addressors can be grasped according to their tone, expression and environment in communication with Japanese with "high-context culture". (6) Female Chinese journalist should answer “はい、わかりました。 ご迷惑をかけてすみませんでした”. (Fine, I understand. I am sorry to trouble you.) First, let others know you understand their "implication" and then apologize for troubling them.

Case analysis method helps students to better understand the reason for intercultural shock; strengthens students' sensibility of non-verbal behavior in intercultural communication; trains students' ability in finding and analyzing problems and understanding domestic and foreign cultures. Besides, it trains students' ability to choose proper 
verbal and non-verbal behavior according to different objects, scenes, contents and situations in communication.

\section{Use Teaching Method of PBL}

PBL is problem-based learning and refers to the studentoriented teaching method in real world. Teaching method of PBL based on constructivism emphasizes students' active learning, in order to let them solve problems through selfexploration and cooperation. In class, the teacher proposes tasks and creates environment of business activities and let students play roles in it. In the classroom of business Japanese, students can discuss cultural conflicts between China and Japan, and draw conclusions.

\section{Task-based Role Playing}

Role playing has various forms. In junior Japanese textbook, role playing is carried out through "lead-in of sentence patterns, role play with sentence patterns" to "consolidate sentence pattern". In business Japanese textbook, role playing is realized through "scene hint, expression exercise, role playing of the same scene", in order to consolidate sentence patterns and expressions.

Task-based role playing is situational simulation. "Students play roles in specific situation and perform what happens through target language." Task-based role playing is obviously different from ordinary role playing. Its characteristics are as follows: (1) The creation of specific situation contains cultural conflicts in communication; (2) Beforehand tasks let students know the objectives in communication; (3) Students have not learnt expressions in completion of task, so they must consider how to speak and take actions. Students independently complete roles allocation, plot discussion and performance; (5) It trains students' analytical thinking and multicultural perspective through performance, observation, analysis, evaluation, discussion and reflection. [6]

Example: how to properly refuse an invitation of leader

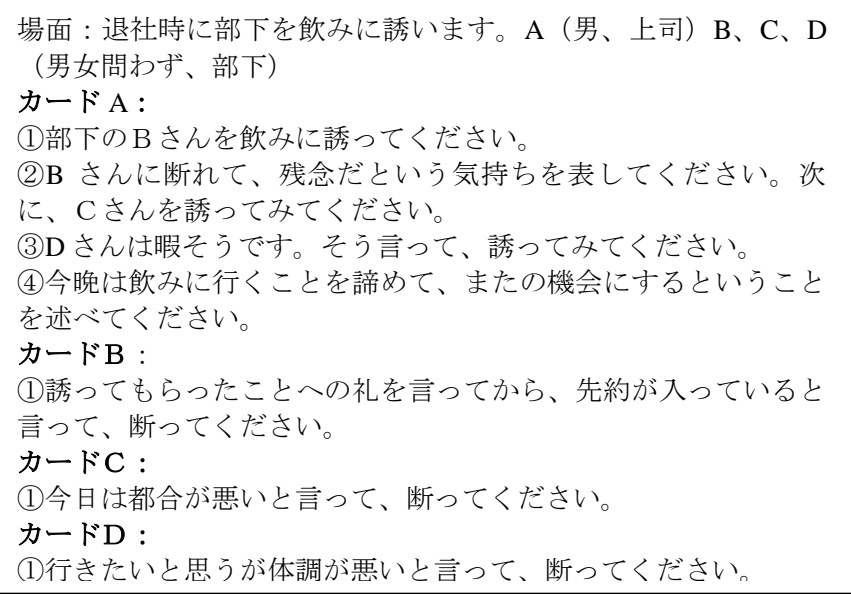

First, provide the specific situation of "how to properly refuse leader's invitation of drinking after work" to students; students are required to complete free grouping, roles allocation and performance within the fixed time; other students analyze and comment on their performance; the teacher give suggestions; students discuss and perform again; the teacher gives final comments. Students understand good interpersonal relationship in business occasion especially in workplace plays an important role in the development of professional career. Therefore, "how to politely refuse leader's invitation through proper language" is the primary task of the role playing The following meanings should be expressed in completion of task: (1) Thanks for the invitation of leader; (2) Express the regrets that you cannot attend because of something; (3) Explain concrete reasons; (4) Express the expectation of next invitation. Students properly use authentic Japanese expressions such as「今回は飲み会のお誘い頂きまして 誠にありがとうございます。大変残念ではございますが」(Thanks for your invitation, but today I am sorry...); 「当日どうしても外 せない用事がございますので、ご辞退させて頂きます事お許しくださ い。」(Because I have something that I cannot refuse to do today, I am sorry I cannot accept your invitation.); 「次回は是非 参加させて頂きますので、またのお誘いを心待ちにしております」(I will accept next time and am looking forward to the next invitation.); 「お声を掛けていただき、ありがとうございます。」 (Thanks for your invitation.); 「残念ながら、その日はすでに予定 があり、参加できそうにありません。」(I am sorry I have had other agenda today.); 「今回のお誘い、大変嬉しく思います。せっ かくお声をかけていただきましたが、当日は別の予定が入っておりま す。」「大変残念ですが、またの機会にお会いできたらと思いま す。」. They fulfill the task smoothly and grasp expressions.

\section{CONCLUSION}

In recent years, the Japanese education in Japan pays special attention to the objective of "learners understand foreign cultures and recognize themselves through communicating with addressors of target language or participating in social group activities" [7]. Knowledge, skills and attitudes are major elements that influence intercultural communication competence. Teachers can transform the teaching thought that centers on vocabularies and grammars and use various teaching methods in class, in order to train students' intercultural communication competence. More teachers are expected to research teaching methods and develop teaching materials that train students' intercultural communication competence.

\section{REFERENCES}

[1] Japanese Group of Foreign Language Teaching Advisory Committee under the Ministry of Education, Syllabus for Elementary Stage of Japanese Major in Universities, Dalian University of Technology Press, 2001

[2] Ministry of Education, National Standard for Teaching Quality of Japanese Major in Universities, Dalian University of Technology Press, 2014

[3] Zhou Linjuan, Pan Youfang. Demand for Japanese and China Business Talents and Reform of Japanese Teaching [J], Journal of Japanese Language Study and Research, 2009(2): 118

[4] Deardorff, The identification and assessment of intercultural competence as a student outcome of international education at institutions of higher education in the United States [D]North Carolina State University, 2004: 194

[5] Xu Yu, 異文化コミュニケーション能力の育成一一日本語教育を中 心に-— [J], Civilization, 21: (NO.28) 65-72 
[6] Zeng Jiajin. Research on Effectiveness of Role Play of Communicative Culture on Intercultural Competence of Second Language Learners [J], Higher Education Exploration, 2014: (4)

[7] 北出慶子.留学生と日本人学生の異文化間コミュニケーション能力 育成を目指した協働学習授業の提案 異文化間コミュニケーショ ン能力理論と実践から [J]. Language and Cultural Education, 2010(9): 67 